HISTORY OF MEDICINE

The Medical Society of London

P Hunting

Postgrad Med J 2004;80:350-354. doi: 10.1136/pgmj.2003.017319

The Medical Society of London was founded in 1773 by the Quaker physician and philanthropist, Dr John Coakley Lettsom, who was convinced that a combined membership of physicians, surgeons, and apothecaries would prove productive. His revolutionary idea met with success and the Society has provided a forum for all branches of the medical profession for the last 231 years. Situated at the heart of London's medical community at Lettsom House, Chandos Street, near Cavendish Square, this is the oldest medical society in the United Kingdom.

$\mathrm{T}$ he history of the Medical Society of London, captured in the following pages, forms a narrative dominated by strong personalities, punctuated by difficulties and set against a background of competition from other societies and the increasing specialisation of medicine. It is remarkable that this modest, non-specialist Society has survived the vicissitudes of two centuries while so many medical societies have dissolved or amalgamated. The secret of the Society's longevity lies in the legacy of Dr Lettsom, a liberal constitution, and the determined pursuit of medical knowledge by a loyal following. In the 1770s the Royal College of Physicians formed an élite accessible only to graduates of Oxford and Cambridge, the Company of Surgeons was dominated by a self electing court, and the Society of Apothecaries was engrossed in trading activities. In these circumstances and in the absence of regular medical journals or periodicals, the Medical Society of London fulfilled a valuable role as the forum for communication between medical practitioners who were anxious to expand the boundaries of medical knowledge and serve the general public.

"The intention of this society will be to give the practitioners in the healing art frequent opportunities of meeting together, and conferring with each other concerning any difficult or uncommon cases which may have occurred; or communicating any new discoveries in medicine which may have been made at home or abroad". ${ }^{1}$ Thus read the manifesto of the Medical Society of London as constituted in 1773. Members of the new Society aimed to advance medical knowledge at fortnightly meetings when physicians, surgeons, apothecaries, and accoucheurs met to share their experiences, exchange information, discuss rare cases, and report medical news. Those working at the London dispensaries were strongly represented among the membership which also embraced naval surgeons,
Quakers, botanists, authors, and antiquarians. All medical practitioners were eligible for membership and individuals were proposed on the basis of personal recommendation-to qualify for election a candidate required the backing of at least three Fellows and a two thirds majority in the secret ballot. If successful he signed the Obligation Book as testimony of his allegiance, then paid an admission fee and the annual subscription.

The Medical Society of London is the senior medical society in Britain-possibly in the world. The Society of Apothecaries is an older foundation, dating from 1617, but it is essentially a City livery company; the Royal Medical Society of Edinburgh dates from 1737 but this was founded for students. Several other medical societies formed in the second half of the 18th century were likewise restricted in their membershipsthe Society of Naval Surgeons and the Society of Licentiate Physicians, for example (neither of which survived the century). The Medical Society of London, on the other hand, was open to all medical practitioners, and therein lay its strength. At meetings of the Society humble apothecaries learnt from licensed physicians, surgeons described daring new operations, physicians of the College heard about the diseases of the sick poor. For the first time the various branches of the medical profession were united in one Society, to mutual benefit. This was the unique appeal of the Medical Society of London.

\section{DR LETTSOM}

The Medical Society of London was the brainchild of Dr Lettsom (fig 1). As founder, President (1775-76, 1784-85, 1808-11, 1813-15), and benefactor Lettsom was the mainstay of the Society from 1773 until his death in 1815. His influence remained strong and his example inspired the next generation of Fellows-men such as Dr Thomas Pettigrew, his biographer, ${ }^{2}$ and Dr Henry Clutterbuck, who followed in Lettsom's footsteps as President of the Society and physician to the General Dispensary. ${ }^{3}$

John Coakley Lettsom was born into the Quaker community on the island of Little Jost Van Dyke in the British Virgin Islands, in 1744. John and his brother were the sole survivors of seven sets of male twins, sons of Edward and Mary Lettsom. John alone was sent to England at the age of 6 to be educated; perhaps he was the strongest twin, he certainly proved to be resilient.

At school in Lancashire the antics of the young Lettsom attracted the attention of the Quaker preacher Samuel Fothergill, who introduced his protégé to his brother, the London physician, Dr John Fothergill. Having completed an 


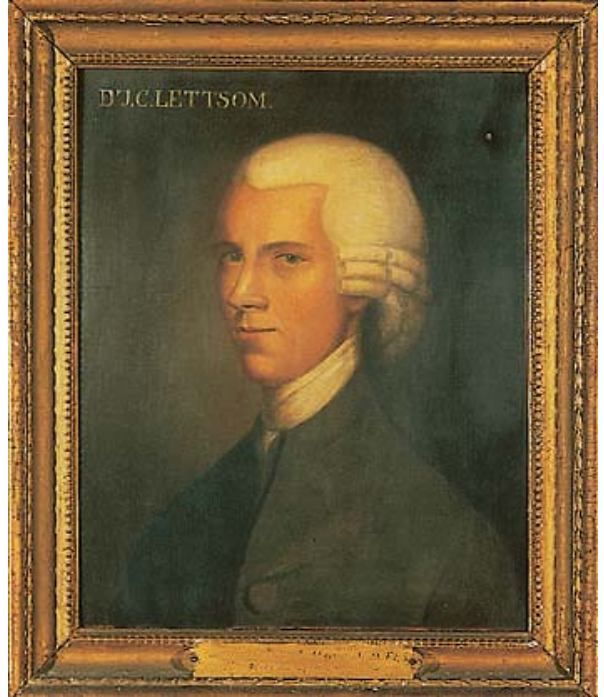

Figure 1 Dr John Coakley Lettsom (1744-1815). A copy of a portrait attributed to Zoffany circa 1782.

apprenticeship to a Yorkshire apothecary, Lettsom came to London in 1766 when through the influence of Dr Fothergill, he commenced a medical training at St Thomas' Hospital. His studies were interrupted by the death of his father, prompting his return to the West Indies where he freed the slaves he had inherited and provided medical care for the local population. Diligence and industry earned him a fortune, enabling him to resume his studies in Europe and culminating in the submission of his MD thesis on the Natural History of the Tea-tree to Leyden University in 1769.

Lettsom's career accelerated with the LRCP and marriage to an heiress. By the age of 30 his reputation as a physician, author, and Fellow of the Royal Society was established. Furthermore, he had founded the General Dispensary in Aldersgate Street and the Medical Society of London. He was a founder-member of the Royal Humane Society in 1774, he initiated the Sea-bathing Infirmary at Margate (1791), became a pillar of the Royal Jennerian Society and gave his support to the Society for the Relief of Widows and Orphans of Medical Men, the Society for the Relief of Debtors, and the Philanthropic Society. Numerous clubs, societies, hospitals, dispensaries, and charitable institutions in the United Kingdom and North America benefited from Lettsom's patronage, while from his pen there flowed a stream of "Hints", pamphlets, diatribes, and letters promoting Sunday schools, female industry, provision for the blind, a bee society, soup kitchens and the mangel-wurzel, and condemning quackery, card parties, and intemperance. ${ }^{4}$ In the diversity of his interests, as physician, philanthropist, botanist, mineralogist and collector, Lettsom was in the mould of that giant of the previous generation of London physicians, Sir Hans Sloane.

\section{DIFFICULT TIMES}

The Medical Society of London was originally constituted for 30 physicians, 30 surgeons, and 30 apothecaries. The number soon increased to encompass a wider range of interests. "The Founders' Picture" (fig 2) reflects the multifarious membership of the Society in its portrayal of eight Fellows of the Royal Society, one baronet (the courtier Sir John Macnamara Hayes), the numismatist Dr Charles Combe, the bespectacled surgeon-oculist James Ware, the notorious Dr Edward Bancroft (a double agent during the American War of Independence), the Mancunian Dissenter Dr John Aikin

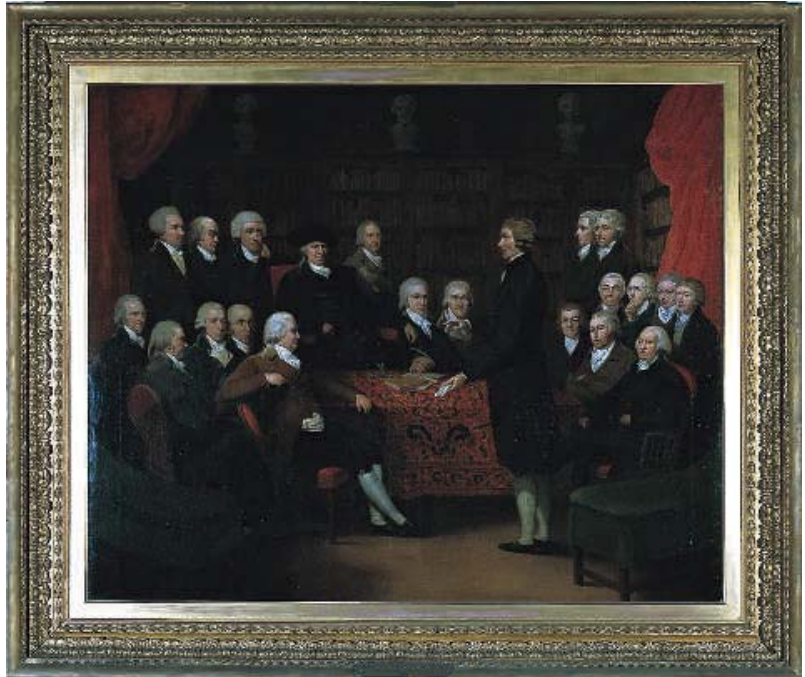

Figure 2 "The Founders' Picture" by Samuel Medley circa 1801. Lettsom addresses a meeting in the Society's library at 3 Bolt Court. The President Dr James Sims is seated, wearing a hat. Dr Edward Jenner stands behind him, dressed in grey.

and Dr Robert Thornton (who published his lavish botanical plates as the Temple of Flora), ${ }^{5}$ grouped alongside seven rebels who were soon to defect to found a rival Society.

The diversity of the membership and tensions between personalities caused arguments in the early years of the Society's history. The first President, Dr John Millar, resigned in 1775 (among others) during a storm of protest, whereupon the Council ordered that his name be "erazed from their books". ${ }^{6}$ One of Millar's successors, Dr Samuel Simmons (who attended George III in his bouts of "insanity"), tendered his resignation within a few months and founded the Society for the Improvement of Medical Knowledge in 1782. The seventh President, Dr John Whitehead (whose career leapt precariously from linen-draper to schoolmaster, pastor and physician to John Wesley), was expelled from the Society in 1784 .

Dissolution was narrowly avoided by the election of Dr James Sims as President in 1786: his leadership brought stability, while Lettsom's gift of a freehold property and the asset of a medical library gave the Society a degree of permanence. However Sims's authoritarian rule as President for 22 years generated resentment, fuelling a crisis when several Fellows seceded to found the Medical and Chirurgical Society in 1805. The parent Society was slow to recover from this blow: its regular publication ceased between 1810 and 1846 and by 1848 "the decadence of the Society" ${ }^{\prime 7}$ led to calls for amalgamation and a move to the West End. Union with the Westminster Medical Society in 1850 boosted membership numbers and the acquisition of 11 Chandos Street in 1872 gave the Society a prestigious address. Moreover, the medical advances of the second half of the 19th century, the stimulation provided by the International Medical Congress of 1881, and a succession of well known Presidents had the effect of increasing the Society's membership to 748 in 1891.

When in 1905 proposals surfaced for the amalgamation of 15 medical societies under the umbrella of the Royal Society of Medicine, the Medical Society suffered a jolt. Pressure to join the Royal Society of Medicine was intense but the membership was divided on the issue. One Fellow predicted that the Medical Society would die of starvation if it remained outside the conglomerate; another warned that to agree to amalgamation was to sign the Society's death 
warrant. ${ }^{8}$ Votes were cast and by a majority of eight the independence of the Medical Society of London was decided.

The Society experienced difficulties of a different nature in 1980. Inflation, lack of a capital fund, and the need for structural repairs at Chandos Street precipitated a financial crisis. Faced with the choice of selling the house or the library, it was decided to dispose of the latter, which had been deposited with the Wellcome Library since 1967. After lengthy negotiations the bulk of the Medical Society's collection of antiquarian books and manuscripts was purchased by the Wellcome Trust for $£ 800000$ in 1984; the collection remains intact at the Wellcome Library, Euston Road, where it is accessible to readers. The sale put the Society's finances on a firm footing and its future at Lettsom House was assured.

\section{MEETINGS}

The Society meets fortnightly during the academic year, as it did in 1773. With the advance of medicine, so the nature of meetings has changed. Initially the emphasis was on current epidemics and the diseases of the poor; in the 19th century smallpox, cholera, and anaesthesia were popular topics; during the world wars of the 20th century Fellows were preoccupied by the medical challenges posed by war. Since the 1990s lectures have diversified so as to appeal to an audience that includes guests and spouses as well as representatives of the many branches of the medical profession. Throughout, the Society has been successful in organising meetings of interest to its broadly based membership.

In 1770 Lettsom founded the General Dispensary for the sick poor of the City and he established the Medical Society three years later as its intellectual counterpart (fig 3). At the Society the staff of the dispensaries that soon sprung up throughout the capital met to confer, and their interests were reflected in the Society's proceedings: fevers, whooping cough, scarlatina, and the common diseases of the poor were regular topics for discussion. Fellows also submitted problematic case histories, demonstrated apparatus and instruments, and argued about the merits of new medicines. Medical intelligence from abroad was welcomed-as the result of the encouragement the Society gave to corresponding members papers and letters were received from medical practitioners in the provinces and overseas. Missives from Dr Benjamin Rush of Philadelphia expounding wild theories about yellow fever provoked controversy, and in 1798 Fellows were astounded to hear news from Dr Edward Jenner in Gloucestershire that "a disease incident to cows, called the cowpock ... when communicated to the human species, is said to remove the liability to smallpox". ${ }^{\prime \prime}$

Jenner's discovery of smallpox vaccination was greeted with incredulity. He had been a corresponding member of the Society since 1789 and in 1800 he attended a meeting to present a copy of his seminal work, An Inquiry into the Cause and Effects of the Variolae Vaccinae (1798). Lettsom and other Fellows of the Society leapt into action, publicising Jenner's discovery and leading the battle to rid the world of smallpox: through their efforts smallpox vaccine reached North America, France, Austria, India, and beyond. Jenner was awarded a special medal and testimonial in 1802 expressing the Society's confidence that "great benefit will accrue to the inhabitants of these Islands, and to mankind in general, from the introduction of Vaccine Inoculation, and that, from their own experience, as well as the extensive and successful trials made in various parts of the world, it will in all probability ultimately eradicate the smallpox". ${ }^{10}$

Whereas Fellows gave wholehearted support to the crusade against smallpox, they were dubious about the claim made in 1785 by Dr William Withering that "foxglove tea" or digitalis was an effective treatment for dropsy. ${ }^{11}$ For 20 years this issue

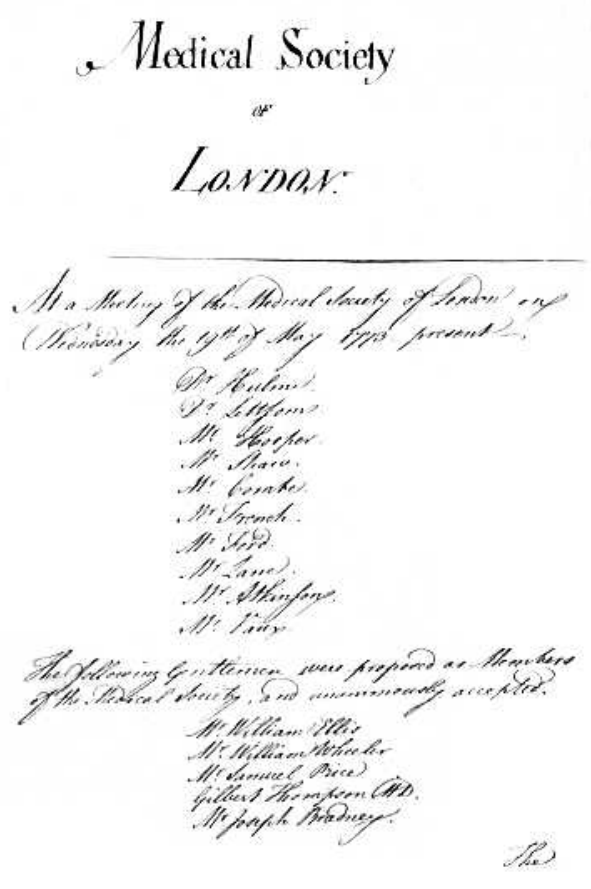

Figure 3 The first meeting of the Medical Society of London was held on 19 May 1773. The founder members were Dr Nathaniel Hulme (physician to the Charterhouse), Dr J C Lettsom (physician to several dispensaries), Dr Joseph Hooper (accoucheur) Joseph Shaw (surgeon), Dr Charles Combe (obstetrician), William French (surgeon), Edward Ford (surgeon), Timothy Lane and William Atkinson (apothecaries), and George Vaux (surgeon).

generated intermittent debate at the Medical Society's meetings. Lettsom conducted his own trials of digitalis and he was not convinced-indeed he warned that "in pulmonary consumption it never cured anyone and that its indiscriminate use had killed many" ${ }^{\prime 2}$ Dr Erasmus Darwin and the surgeon John Addington led the opposing argument and the value of digitalis continued to be "much disputed" among the membership. ${ }^{13}$

When in March 1803 the number of deaths in London from influenza rose to 537 a week, the Society embarked on a new initiative: an investigation by postal survey. ${ }^{14}$ In order to obtain further information about the epidemic 200 circulars were sent to members at home and abroad. The Post Master General granted free postage on the grounds that the inquiry would benefit the human race, and replies were received from as far afield as Martinique. ${ }^{15}$ The Society was to conduct similar investigations into arsenic poisoning (from wallpaper, artificial flowers, and confectionery) in 1881 and on the long term results of operations for carcinoma of the breast in 1923.

A pandemic of cholera preoccupied the Society in 1852-53 when discussions were led by Dr John Snow: his thesis that cholera was waterborne was to be ratified when he traced a source of contamination to the Broad Street Pump (1854); his findings are now recognised as a milestone in the science of epidemiology. Snow was also a pioneer anaesthetist; as President of the Society (1855-56) he strongly recommended the use of chloroform in surgery on those wounded in the Crimean War. ${ }^{16}$

Not all meetings consisted of papers, discussions, and medical intelligence. New instruments for military surgery, resuscitation apparatus sent from Paris, specimens, and patients were exhibited and in 1797 "a leg in a keg" received 
from William Balmain in Australia was examined. ${ }^{17}$ The stethoscope, recently invented by Laennec, was introduced to Fellows at a meeting in 1820 as a new method of diagnosis in thoracic diseases, ${ }^{18}$ and in 1882 Dr Benjamin Howard parked the first London ambulance in Chandos Street while he tried to convince his audience that an ambulance service would save lives in a dangerous city. ${ }^{19}$ Another novelty, "the new shadow photography by Röntgen's X-rays" was demonstrated at a meeting in $1896 .{ }^{20}$

When the nation was at war members concentrated on the medical challenges this presented. Dr Nathaniel Hulme, a founding Fellow, was an authority on scurvy and Sir Gilbert Blane's investigation into the fever that paralysed the army at Walcheren in 1809 earned him a baronetcy. It was at a meeting of the Medical Society that Leonard Gillespie, who was responsible for the health of the crew of Lord Nelson's flagship HMS Victory, learnt that large quantities of orange and lemon juice cured "sea-scurvy". ${ }^{21}$

Fellows saw active service in the Crimean War, the Boer War, the Franco-Prussian War, and two world wars. The "war meetings" of 1939-45 dealing with burns, the effects of underwater explosions, and the use of X-rays in air-raid casualties did not falter-even though the Society's house was damaged when a bomb exploded in Langham Place. More recently, Surgeon Commanders G G Williams, R T Jolly, and R J Leicester told of their experiences of naval medicine during the Falklands conflict (1983), ${ }^{22}$ and Professor Simon Wessely spoke about health problems pursuant on the Gulf War (2003)..$^{23}$

During the peaceful years after the second world war members were brought up-to-date on the uses and abuses of penicillin by Sir Alexander Fleming (1945), the dangers of antibiotics (1956), the use of ultrasound (1963), the EMI scan (1977), and AIDS (1985). With the admission of women Fellows from 1969 and the introduction of buffet suppers in 1976 meetings have become less formal and more sociable. The Society's annual programme now includes visits abroad and Christmas celebrations, while the regular lectures aim to cover a wide spectrum of interest from medical services in British motor racing (1996) to Leonardo da Vinci as an anatomist (2002).

\section{LORD LISTER}

Professor Lister's paper describing the antiseptic methods he had used successfully in 11 compound fracture cases was first published in the Lancet of 16 March 1867. The medical profession was not easily persuaded and "Listerism" was still controversial when its originator came to London a decade later. Soon after his arrival, Lister joined the Medical Society, for here he found a platform from which to promulgate his antiseptic methods. He began by insisting that pyaemia is prevented by the use of antiseptic precautions and that antiseptic treatment was of special value in surgery of the joints (1879). ${ }^{24}$ Lister was still arguing his case in 1883: "By antiseptic means we can do, and are bound to do, operations of the greatest importance for our patients' advantage, which, without strict antiseptic means, the best surgeon would not be justified in recommending". At last, at the conclusion of this paper, Lister was acclaimed. "Gentlemen" he replied, "I thank you most heartily for that cheer; for there was a time when such remarks proceeding from me might have met with a different reception" ${ }^{25}$

Lord Lister continued to contribute papers to the Society and was nominated President-elect in 1896; he declined graciously but gave the Annual Oration in 1891. As his nephew and biographer perceived, Lister favoured this Society above all others-most conspicuously by leaving it his medical library. Some 2500 books from his personal collection were received soon after his death in 1912. ${ }^{26} 27$

\section{THE SOCIETY'S HOUSES}

After meetings held in taverns and rented accommodation in Crane Court, the Medical Society was presented with a freehold property, 3 Bolt Court, Fleet Street, in $1787 .^{28}$ The house was the gift of Dr Lettsom, who also presented the Coade stone plaque originally above the front door at Bolt Court and now in the Society's meeting room. The possession of a house as a permanent base with space for a library of some 40000 books and accommodation for the Registrar reinvigorated the Society. The first volume of its Memoirs was published in 1787, prize medals and diplomas were instituted, and dissension among the membership subsided.

By the mid-19th century London's medical community congregated in the West End and Fleet Street was no longer a convenient rendezvous for Fellows of the Medical Society. Therefore, on amalgamation with the Westminster Medical Society in 1850, the Society moved to 32A George Street (now Saint George Street), Hanover Square, thence to 11 Chandos Street in March 1873 (fig 4). ${ }^{29}$ This early 19th century house belonging to the Earl of Gainsborough suited the Society admirably, and with the purchase of the freehold of numbers 10A to 12 Chandos Street in 1928, the Medical Society of London was entrenched at the heart of the medical fraternity.

\section{SURVIVAL}

At least a dozen medical societies were founded in London during the late 18th century; only four survived to 1810. They were replaced by new societies, notably the Hunterian Society (1819) and the Harveian Society of London (1831), and by the 1880s the capital was saturated with specialist medical societies. Many of these were swallowed up by the Royal Society of Medicine in 1907 and in 2004 only a handful of independent medical societies remain active. The Medical Society of London, now in its 231st session, is the oldest and most prosperous. Its role has expanded in line with the liberal principles of its founders; members are drawn from different disciplines and meetings covering a wide range of subjects are conducted in a congenial atmosphere. At Lettsom House the library, archives, paintings, and memorabilia are treasured and additions to the collections are acquired regularly. Not only is Lettsom House the Society's much-loved home, it also functions as the headquarters of other societies in the firmament. Here Presidents of Royal Colleges, Masters of livery companies, generals, admirals, professors, general practitioners, and specialists congregate to confer, socialise, and learn from one other, as Lettsom had intended.

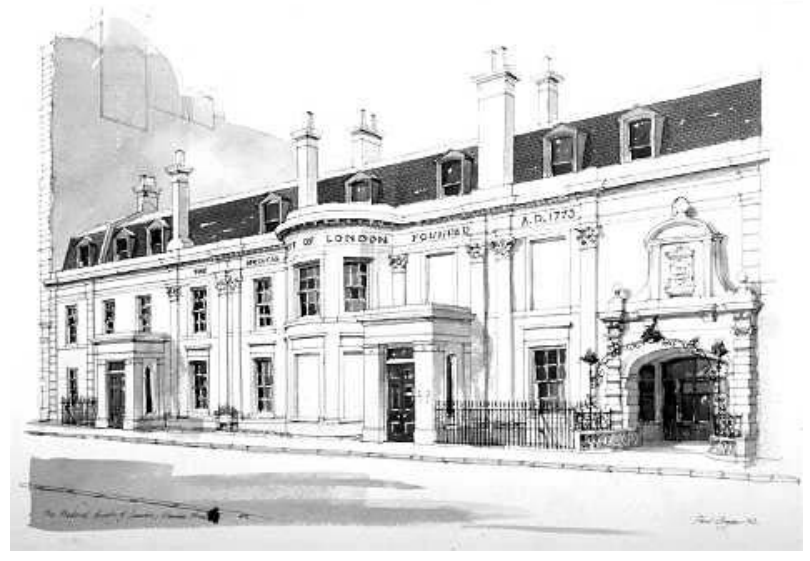

Figure 4 The Society's house at 11 Chandos Street. A watercolour by Paul Draper, 1992. 
The main sources for this article are The Medical Society of London 1773-2003 by Dr Penelope Hunting (2003), available from the Society at 11 Chandos Street, London WIG 9EB, and Dr J J Abraham's biography, Lettsom. His Life, Times, Friends and Descendants. London: W Heinemann Ltd 1933. The Society's Minute Books and other archives are located at 11 Chandos Street. The illustrations are reproduced by kind permission of the Society.

\section{REFERENCES}

1 Medical Society of London. Laws of Medical Society of London. London: Medical Society of London, 1773.

2 Pettigrew TJ. Memoirs of the life and writings of the late John Coakley Lettsom. London: Nichols, Son and Bentley, 1817

3 Storey G. Henry Clutterbuck (1767-1856). Journal of Medical Biography 2000:8:16-22.

4 Lettsom JC. Hints designed to promote beneficence, temperance and medical science. London: J Nichols, 1801.

5 Thornton RJ. Temple of flora. London: Dr Thornton, 1807, 1812.

6 Medical Society. Council minutes. London: Medical Society, 21 February 1775.

7 Medical Society. Council minutes. London: Medical Society, 5 May 1848.

8 Medical Society. General meeting minutes. London: Medical Society, 29 October 1906.

9 Medical Society. Ordinary minutes. London: Medical Society, 18 June 1798

10 Medical Society. Council minutes. London: Medical Society, 22 March 1802.

11 Withering W. Account of the foxglove and some of its medical uses with practical remarks on dropsy and other diseases. London, 1785.
12 Pettigrew TJ. Memoirs of the life and writings of the late John Coakley Lettsom. London: Nichols, Son and Bentley, 1817;3:348.

13 Medical Society. Ordinary minutes. London: Medical Society, 11 February 1805.

14 Medical Society. Council minutes. London: Medical Society, 16 May 1803.

15 Medical Society. Memoirs of the Medical Society of London, London, 1805;6:596-600.

16 On the cause and prevention of death from chloroform. Lancet 9 February 1856:154-6.

17 Medical Society. Council minutes. London: Medical Society, 4 September 1797, 30 April 1798

18 Cholmeley W. Annual oration. The advancement of therapeutics and the science of medicine. Medical Times and Gazette 6 May 1871:521-4.

19 Howard B. Hospital and accident ambulance service for London. Lancet 4 February 1882:172-6

20 Medical Society. Ordinary minutes. London: Medical Society, 24 February 1896.

21 Gillespie L. Journal, 2 October 1786 ADM 101/02/2 [Public Record Office]

22 Naval medicine in the Falklands Conflict. Transactions of the Medical Society of London 1982-83;99:75-93.

23 Wessely S. Transactions of the Medical Society of London (in press).

24 Medical Society. Ordinary minutes. London: Medical Society, 3 March 1879.

25 Lister J. On the treatment of fracture of the patella. BMJ 1883;ii:855-60.

26 Godlee Rickman J. Lord Lister. London: Macmillan, 1917:480-84.

27 Cope VZ. The profession of surgery. Transactions of the Medical Society of London 1940-43;63:1-8.

28 Indenture. Medical Society of London archives, 28 September 1787.

29 Medical Society. Council minutes. London: Medical Society, 28 October, 7 November 1872.

\section{IMAGES IN MEDICINE}

\section{Bullosis diabeticorum}

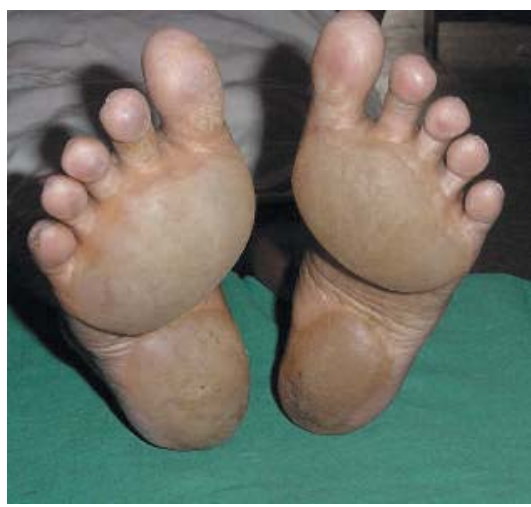

Figure 1 Soles of patient showing tense bullae.

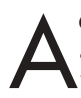
62 year old woman, who had type 2 diabetes of 15 years' duration, developed community acquired pneumonia. Her sensorium was normal. Skin examination revealed bilateral tense painless bullae on her soles and toes (fig 1). She had peripheral sensory motor neuropathy. Bullae aspiration revealed clear fluid. Immunofluorescent studies and fluid cultures were negative. The bullae healed over two weeks.

About $0.5 \%$ of diabetics develop diabetic bullae or bullosis diabeticorum, a distinct diabetic marker. The bullae occur more frequently in adult men with long standing diabetes and neuropathy. The pathogenesis of diabetic bullae is unclear. These painless bullae may be the first presentation of diabetes, appearing suddenly, commonly on lower limbs. They range in size from a few millimeters to several centimeters, have a non-inflamed base, and contain clear sterile fluid.

The differential diagnosis includes several bullous disorders; diagnosis is of exclusion. Healing is spontaneous in a few weeks but they may reoccur.

K P Anand, A S Kashyap Department of Medicine, Armed Forces Medical College, Pune 41 1040, India; kpkpa49@yahoo.co.in 